\author{
Faculty Research Working Papers Series
} The Moral Case for a Human Right to Relocation: Disappearing Island Nations
and Common Ownership of the Earth

\author{
Mathias Risse \\ John F. Kennedy School of Government - Harvard University
}

October 2008

RWP08-054

The views expressed in the HKS Faculty Research Working Paper Series are those of the author(s) and do not necessarily reflect those of the John F. Kennedy School of Government or of Harvard University. Faculty Research Working Papers have not undergone formal review and approval. Such papers are included in this series to elicit feedback and to encourage debate on important public policy challenges. Copyright belongs to the author(s). Papers may be downloaded for personal use only. 


\title{
The Moral Case for a Human Right to Relocation: Disappearing Island Nations and Common Ownership of the Earth
}

\author{
Mathias Risse \\ John F. Kennedy School of Government, Harvard University \\ October 17, 2008
}

(about 9,000 words)

\begin{abstract}
In recent work I have tried to revitalize the standpoint of humanity's commonly owning the earth. This standpoint has implications for a range of problems that have recently preoccupied us at the global level, including immigration, obligations to future generations, climate change, and human rights. In particular, this approach helps illuminate what moral claims to international aid small island nations have whose existence is threatened by global climate change. A recent proposal for relocating his people across different nations by President Tong of Kiribati is a case in point. My approach vindicates President Tong's proposal.
\end{abstract}

Key Words: Common Ownership; Human Rights; Small Island Nations; AOSIS; Climate Change; Immigration

1. Kiribati consists of 33 coral atolls that straddle the equator and are scattered over 3.5 million square kilometers in the vast central area of the Pacific Ocean. The capital, Tarawa, is half way between Hawaii and Australia. Umberto Eco's novel The Island of the Day Before might well be taking place there since Kiribati is also straddling the International Date Line. Taken together, the islands are about four times the size of Washington, DC, but have a coastline of more then 1,100 km. Although with a birthrate of four children per woman the island's demographic development is in good shape, Kiribati's continued existence is in jeopardy. The islands might well become uninhabitable due to rising sea levels and salination caused by global climate change. In response to this, Anote Tong, Kiribati's president, has proposed an extraordinary plan, 
namely, to scatter his people of about 100,000 through the nations of the world as rising sea levels swallow up their native islands. ${ }^{1}$

That proposal is a back-up plan - ideally, Kiribati’s government is looking for a piece of land where its people can move as a whole. But assuming that to be rather unrealistic, they pursue the aforementioned plan as a more palatable alternative. Tong would have groups of Kiribati citizens — perhaps 1,000 per year — receive job training and then seek skilled jobs in other nations. Later on, others could turn to these early emigrants to facilitate their own exit as the environmental situation worsens at home. As of 2008, this plan has already begun to be implemented, with small groups of nurses going to Australia for training and other workers to New Zealand. Other small island countries, as well as low-lying coastal countries, have similar problems. Since 1990, a large number of such countries have formed the Association of Small Island States (AOSIS). The main purpose of the alliance is to articulate the concerns of these countries about global climate change. AOSIS has 43 members and observers from around the world, representing, $28 \%$ of the developing countries, $20 \%$ of the United Nation's total membership, and $5 \%$ of the world population. ${ }^{2}$ So there is nothing peculiar about Kiribati's predicament except that its president has been rather vocal recently in terms of addressing the pending doom that threatens them all, although inevitably to different degrees.

\footnotetext{
${ }^{1}$ For facts about Kiribati, see for instance the CIA fact book, https://www.cia.gov/library/publications/theworld-factbook/geos/kr.html. The proposal was made, for instance, during a talk at Harvard University in September 2008, see http://www.news.harvard.edu/gazette/2008/09.25/13-kiribati.html. See also http://www.un.org/ga/63/generaldebate/pdf/kiribati_en.pdf and http://WwW.fmreview.org/FMRpdfs/FMR31/51-52.pdf

${ }^{2}$ The official AOSIS site is here: http://www.sidsnet.org/aosis/index.html
} 
What support from moral arguments might there be for Tong's proposal? Different approaches are possible. The inhabitants of Kiribati have done less on a per capita basis than those of almost any other country to cause climate change in the first place. They have never had much of an industry. Surely, one might say, what is owed to them is that either those activities stop that cause their troubles, or else - if, for example, there is no longer the option of saving the islands their fate - they should be compensated. As far as compensation is concerned, it seems the president's plan is rather sensible. This strategy is worth pursuing, but also encounters difficulties. Many of those who over the decades have contributed to the causes of the difficulties were not aware, and could not be aware, of what damage they were doing. Or one may argue that, even if the kind of responsibility involved is strict liability, rather than fault-based, the inhabitants of Kiribati have no claims to particular attention since they have in many ways benefited from the global economic changes to which the causes of climate change have been tied. ${ }^{3}$

There might of course be answers to these difficulties, but regardless of where the verdict on this strategy falls, it is advisable to have an alternative strategy to support Tong's proposal. My goal is to offer such an alternative. This other strategy consists in arguing that the inhabitants of Kiribati, like all other human beings, are co-owners of the earth and as such have claims to relocation if their existence becomes impossible where they live. They can press these claims regardless of whether it was anybody else's fault that they found themselves in this situation to begin with.

\footnotetext{
3 There has been a good deal of discussion about historical emissions and possible obligations emerging from them. See Shue (1996), (1999), Gardiner (2004), Caney (2006a), (2006b), (2008), Grubb et al (1992), Gosseries (2004), Singer (2002).
} 
That humanity collectively owns the earth was the predominant idea in the political philosophy of the $17^{\text {th }}$ century: Grotius, Hobbes, Pufendorf, Filmer, Locke, and others debated how to capture this status and the conditions under which groups or individuals can privatize parts of the Global Common. ${ }^{4}$ It was a natural idea to champion in response to many of the urgent questions of the age as they appeared to philosophers concerned with political matters. It was in the $17^{\text {th }}$ century that European expansionism came into its own. There was a host of questions about the conditions under which European thinkers thought what portions of overseas territories could be appropriated, and under what conditions the natives could be displaced. The standpoint of collective ownership of the earth lent itself to the resolution of those problems not only because these were issues of genuinely global scope (although the relevant audience in the minds of the writers involved in that debate were Europeans only), but also because this standpoint was still available despite the religious troubles of the age. After all, collective ownership of the Earth was warranted by a divine gift reported in the Book of Genesis. That gift was undisputed among the relevant audience.

Although collective ownership was then largely religiously motivated, we can revitalize it non-theologically. Doing so is sensible in light of all those problems of global reach that have recently preoccupied us, such as questions about immigration, responsibility for future generations, and global climate change. In recent work I have also argued that the idea of collective ownership of the earth gives rise to a particular conception of human rights. In virtue of the fact that humanity collectively owns the earth, individuals possess a set of natural rights that characterize their status as co-

\footnotetext{
${ }^{4}$ See Buckle (1991) and Tuck (1999) for general introduction to these discussions.
} 
owners. The existence of states puts these rights in jeopardy, and a set of associative rights must make sure states preserve these natural rights. These associative rights turn out to provide us with a conception of human rights, where such rights are membership rights in the global order and where the standpoint of collective ownership serves as one basis for the derivation of these rights. ${ }^{5}$

While this view may strike many as missing the point of human rights, it has its virtues: it rests on foundations that should be universally acceptable; can readily demonstrate why the language of "rights" rather than goals is appropriate here; and entails a genuinely global responsibility for these rights. As far as the perhaps counterintuitive connection between human rights and ownership is concerned, one needs to keep in mind that what is at stake here is the sheer space in which all human existence takes place. At any rate, it should be of general interest to bring this revitalization of the ownership approach to bear on problems caused by global warming, which after all is the paradigmatic problem affecting our planet as a whole. In particular, according to the conception of human rights that we can develop in this way, the inhabitants of Kiribati do have an actual human right to the relocation envisaged by Tong's proposal. The main goal of this essay is to articulate enough of this approach to human rights to explain how it does provide such support for his proposal. At the same time, I hope to make the ownership approach per se plausible in such a way that it can still deliver support for

\footnotetext{
${ }^{5}$ I am developing this standpoint of collective ownership in detail as part of a forthcoming book called The Grounds of Justice. For this particular approach to human rights, see Risse (2009a), (2009b), and Risse (forthcoming). For the application of this approach to immigration, see Blake and Risse (2007), Blake and Risse (forthcoming), and Risse (2008).
} 
Tong's cause even in the eyes of those who do not accept my argument for the connection between the standpoint of collective ownership and human rights.

2. It is probably John Locke whose account of collective ownership of the earth is nowadays best known, especially in connection with his famous "mixing-of-labor" approach to private appropriation. Yet my own attempts to revitalize the collectiveownership approach draw inspiration mostly from Hugo Grotius. To reacquaint the reader with an approach that is no longer part of mainstream political thinking, let me start with some comments on Grotius. ${ }^{6}$ Like no other work in the philosophy of international relations, Grotius' De Jure Belli ac Pacis Libri Tres (DJB), Three Books on the Law of War and Peace, published in 1625, makes ownership of the earth central to regulating the relations among both individuals and political entities. Grotius' concern is with the "differences of those who do not acknowledge one common Civil Right whereby they may and ought to be decided” (I.1.I), differences he seeks to regulate non-parochially. By making collective ownership central, Grotius formulates a version of a standpoint of what one may call global public reason.

Grotius famously offers the following account of collective ownership of the earth: ${ }^{7}$

Almighty God at the creation, and again after the Deluge, gave to Mankind in general a Dominion over Things of this inferior World. All Things, as Justin has it, were at first common, and all the World had, as it were, but one Patrimony. From hence it was, that every Man converted what he would to his own Use, and consumed whatever was to be consumed; and such a Use of the Right common to all Men did at that time supply the Place of Property, for no Man could justly take from another, what he had thus first taken to himself; which is well illustrated by that Simile of

\footnotetext{
${ }^{6}$ An exception to this comparative neglect of this kind of thinking in recent political thought is leftlibertarianism; see Vallentyne and Steiner (2000a) and (2000b).

${ }^{7}$ I quote from DJB in the customary manner, for instance “ II.2.II.1.” this means: Second volume; second book; second chapter; first section. The 2005 Liberty Fund edition is especially accessible.
} 
Cicero, Tho' the Theatre is common for any Body that comes, yet the Place that every one sits in is properly his own. And this State of Things must have continued till now, had Men persisted in their primitive Simplicity, or lived together in perfect Friendship. (DJB, II.2.II.1)

God's gift can rightfully be put to use without any agreement. But this only works under primitive conditions, and does not even include a right to recover things left behind. Agreement is needed to create further-reaching rights, at least according to the account in De Jure Belli ac Pacis. Still, God's gift makes clear that the earth is for the use of human beings. As Buckle (1991) puts it, "in using the world for their own ends, human beings are not strangers (or trespassers) on a foreign soil. They are at home” (p 95).

Once primitive conditions have been left behind, property arrangements are conventional. To be adequate, these conventions must mind the fact that the earth was originally given to humankind collectively. One implication of this point is the postulation of a "right of necessity;" for

in a case of Absolute Necessity, that antient Right of using Things, as if they still remained common, must revive, and be in full Force: For in all Laws of human Institution, and consequently, in that of Property too, such cases seem to be excepted. (DJB, II.2.VI.2)

This right does not derive from charity (II.2.VI.4). Instead, it restricts private property rights as they could have been intended, or at any rate, their legitimate scope. After all, in addition to his account of the divine gift, Grotius also offer an account of natural rights that include "the Abstaining from that which is another's, and the Restitution of what we have of another's, or of the Profit we have made by it, the Obligation of fulfilling Promises, the Reparation of a Damage done through our own Default, and the Merit of Punishment among Men.” Society was formed for the protection of what is one's own, the suum (DJB, I.2.I.5), and a sphere of what is ours exists prior to actual property 
arrangements. Whereas Hobbes thought the most basic insight one could make uncontroversial was that everybody had a right to self-preservation, Grotius started with a number of laws of nature in which what individuals have a right to is spelled out in ways meant to be reasonable for everybody. Grotius is guided by solidaristic assumptions, and an understanding of humanity as susceptible to moral motivation in principle.

Some limitations to property are not rights of necessity but general restrictions of what may be claimed under any conditions. Others may avail themselves of innocent profits (e.g., sail on our rivers), or demand free passage (even when trading with third parties, II.2.XI-XIII), rights that if denied can be claimed by force (II.2.XIII.3). People may rest ashore to recover from a journey, even build “a little Cottage” (II.2.XV.2), and seek "a fixed Abode" (II.2.XVI.2) if prosecuted at home, assuming they abide by local laws. Products must be sold at reasonable prices if they are not needed by the producers (II.2.XIX). Even the right to marriage ought not to be denied, women apparently being part of the common stock (II.2.XXI). All these rights are owed to all, not just a selected few (II.2.XXII). These strong constraints on ownership are much at odds with our current practices. As a striking illustration, consider cases of forced immigration:

And if there be any waste or barren Land within our Dominions, that also is to be given to Strangers, at their Request, or may be lawfully possessed by them, because whatever remains uncultivated, is not to be esteemed Property, only so far as concerns Jurisdiction, which always continues the Right of the antient People. (II.2.XVII).

As these cases make clear already, the collective ownership status of the earth, in conjunction with the additional natural rights Grotius postulates, puts considerable limitations on what can be done with resources and portions of the earth. The 
corresponding point about the secularized version of Grotius' account will be of great importance below when we return to the fate of Kiribati.

3. While Grotius takes the biblical standpoint of the earth as a divine gift, like Locke he held that this view should be acceptable even if humankind had never received that revelation. Indeed, the view that the earth originally belongs to humankind collectively remains plausible without religious input. Philosophically, much can be gained by developing, in secular ways, the idea that humanity collectively owns the earth, since this original ownership status has strong implications for what individuals and group can do with portions of the three-dimensional space that has this status. Among other things, this standpoint generates constraints on what immigration policies a state can adopt, and it also leads to a particular conception of human rights. To motivate this secularization of the standpoint of collective ownership, notice that two points are obvious enough: first, the resources of the earth are valuable and necessary for any human activities to unfold; and second, those resources have come into existence without human interference. These points must be considered when individual accomplishments are used to justify property rights strong enough to determine use across generations. ${ }^{8}$

Egalitarian Ownership is the view that the earth originally belongs to humankind collectively, in the sense that all humans, no matter when and where they are born, must have some sort of symmetrical claim to it. ("Original” ownership does not connote with time but is a moral status.) I assert that this is the most plausible view of the ownership of natural resources, because of the two points mentioned above: that the existence of the

\footnotetext{
${ }^{8}$ There is an enormous literature on the foundations of property; see Becker (1977), Reeve (1986), or Ryan (1987) for overviews.
} 
resources of the earth is nobody's accomplishment, whereas they are needed for any human activities to unfold. Egalitarian Ownership is detached from the complex set of rights and duties civil law delineates under the heading of property law (Honore (1961)). At this level of abstraction from conventions and codes that themselves have to be assessed in relation to views on original ownership, all Egalitarian Ownership states is that all humans have a symmetrical claim to original resources.

One may say that the term "ownership” is misleading here, but I use it since there is this connection to the familiar, thicker notions of ownership in civil law; and we are, after all, concerned with what sorts of claims individuals have to resources. To be sure, the considerations motivating Egalitarian Ownership speak to raw materials only, not to what human beings have made of them. The distinction between what "is just there" and what has been shaped by humans is blurred, say, for land human beings have wrested from the sea, or for natural gas harnessed from garbage deposits. But by and large, we understand well enough the idea of what exists without human interference. ${ }^{9}$

In a next step, we must assess different conceptions of Egalitarian Ownership. Such conceptions differ in terms of how they understand the symmetry of claims individuals have to original resources. There are, roughly, four types of ownership-status an entity may have: no ownership; joint ownership - ownership directed by collective

\footnotetext{
${ }^{9}$ A much more difficult question is under what conditions man-made products, including improvements of original resources, should no longer be accompanied by special entitlements of those who made them or their offspring. See Blake and Risse (forthcoming) for discussion. Egalitarian Ownership formulates a standing demand on all groups that occupy parts of the earth to inhabit the earth in a manner that respects this symmetrical status of individuals with regard to resources. That Egalitarian Ownership operates in this way should be intelligible and acceptable even within cultures where individuals are not seen as property owners. Nothing about Egalitarian Ownership precludes such cultures from being acceptable to their members even if they do not treat individuals themselves as property holders. At the same time, even cultures that do not see individuals themselves as property holders must indeed be acceptable to those who live in them especially because all individuals have symmetrical claims to original resources, no matter how precisely we understand such acceptability.
} 
preferences; common ownership - in which the entity belongs to several individuals, each equally entitled to using it within constraints; and private ownership. Common ownership is a right to use something that does not come with the right to exclude other co-owners from also using it. If the Boston Common were held as common ownership when it was used for cattle, a constraint on each person's use could be to bring no more than a certain number of cattle, a condition motivated by respect for other co-owners and the concern to avoid the infamous Tragedy of the Commons. Yet if they held the Common in joint ownership, each individual use would be subject to a decision process to be concluded to the satisfaction of each co-owner. Joint ownership ascribes to each co-owner property rights as extensive as rights of private ownership, except that others hold the same rights: each co-owner must be satisfied on each form of use.

So there are various interpretations of Egalitarian Ownership: resources could be jointly owned, or commonly owned, or each person could have private ownership of an equal share of resources, or its value equivalent. That is, these conceptions all carve out a pre-institutional space of natural rights that constrain property conventions which in turn regulate what these natural rights leave open. I submit that Common Ownership is the most plausible conception. ${ }^{10}$ While I cannot offer a complete argument for this proposal here, I can offer elaboration on what common ownership means, what it entails, and why

\footnotetext{
${ }^{10}$ In capital letters, “Joint Ownership” and “Common Ownership” are names of interpretations of Egalitarian Ownership and hence views about ownership of the earth, whereas in small letters "joint ownership” and "common ownership” are general forms of ownership of anything. I will continue to say that humanity "collectively" owns the earth if the precise form of ownership does not matter.
} 
it should be preferred to the other conceptions as an interpretation of Egalitarian Ownership. $^{11}$

The core idea of common ownership is that all co-owners ought to have an equal opportunity to satisfy their needs to the extent that this turns on obtaining collectively owned resources. This formulation, first, emphasizes an equality of status; second, it points out that this equality of status concerns opportunities to satisfy needs (whereas there is no sense in which each co-owner would be entitled to an equal share of what is collectively owned, let alone to the support of others in getting such a share, any more than any co-owners of the Boston Common had a claim to such a share or to the support of others to obtain it); and third, it does so insofar as these needs can be satisfied with resources that are collectively owned (that is, nothing at all is said about anything to which the original intuitions motivating Egalitarian Ownership do not apply).

To put this in the Hohfeldian rights terminology, common ownership rights must minimally include liberty rights accompanied by what Hart (1982) calls a "protective perimeter" of claim rights ( $\mathrm{p} 171$ ). ${ }^{12}$ To have a liberty right is to be free of any duty to the contrary, and obviously, common ownership rights must include at least rights of that sort; that is, co-owners are under no duty to refrain from using any of the resources of the earth. But the symmetry of claims postulated by Egalitarian Ownership demands more than liberty rights. In light of the intuitions supporting Egalitarian Ownership, to count as an interpretation of it, Common Ownership must guarantee some minimal access to

\footnotetext{
${ }^{11}$ Risse (2005) offers supportive arguments, showing why the other possible conceptions are independently problematic, and I develop all of this at much greater length in my forthcoming book on The Grounds of Justice. See also Risse (2009a)

${ }^{12}$ For the Hohfeld terminology, see for instance Edmundson (2004), chapter 5.
} 
resources, that is, impose duties to refrain from interference with certain forms of use of resources. Therefore we must add that protective perimeter of claim rights to the liberty rights. We can obtain enough mileage from the original intuitions to require that common ownership rights (for Common Ownership to serve as an interpretation of Egalitarian Ownership) be conceived of in sufficientarian terms, in the sense that no co-owner should interfere with the actions of another to the extent that they serve to satisfy basic needs. I do not think these intuitions can be pressed beyond that. Equal Division and Joint Ownership both press these intuitions too far.

Yet we do have to add one more right. We must also make sure individuals can maintain their co-ownership status under more complex arrangements. A necessary condition for the acceptability of such arrangements is that the core purpose of the original rights can still be met. That core purpose is to make sure co-owners have the opportunity to meet their basic needs. In Hohfeldian terminology, co-owners have an immunity from living under political and economic arrangements that interfere with the ability of those subject to them having such opportunities.

Let me quickly address a typical reductio through which right-libertarians often ridicule collective ownership and that resonate with many readers. Can somebody seriously claim, asks Murray Rothbard, that a newborn Pakistani baby has a claim to a plot in Iowa that Smith transformed into a field ${ }^{13}$ As soon as one considers such implications of collective ownership, says he, one realizes its implausibility. Smith has claims on the strength of his plight, but the baby has none. This argument gains rhetorically from emphasizing features of the protagonists that are irrelevant to what

\footnotetext{
13 Rothbard (1996), p 35; Hospers (1971), p 65, makes a similar point.
} 
claims the baby may have. More importantly, collective ownership of the sort we will defend does not grant each and every individual claims to each and every object. Not any nugget of gold found on the ocean floor has to be shared out among all human beings, nor does each drop of oil extracted in Arabia. That our baby has claims to resources on a par with Smith's is consistent with its not having claims on Smith to vacate that land. While a detailed view of what collective ownership amounts to has yet to be established, collective ownership is not so easily shown to be absurd.

4. Yet although humanity owns the earth collectively, and although the high seas and Antarctica are treated as a Global Common, ${ }^{14}$ the remaining land is covered by states. States reserve the right to determine who enters their territory, and it is through state law that local property conventions are enforced, conventions that regulate access to both original resources and entities whose existence depends on human input. Such a political system is not inconsistent with Common Ownership, but the imposition of a system of states that divide up the world's resources needs to be reconciled with Common Ownership, for two reasons. First, each state imposes a complex system of political and economic relationships that determines which, if any, original resources individuals have access to. Second, a system of states imposes a system of ownership where groups claim (group-specific) collective ownership for certain regions. Co-owners are excluded from exercising rights with regard to much of what is collectively owned.

One way in which to assess how to reconcile the presence of a state system with Common Ownership is to explore the implications of the standpoint of collective

\footnotetext{
${ }^{14}$ See Malanczuk (1997), pp 149f and pp $184 \mathrm{ff}$. Outer space is also treated in this way.
} 
ownership for immigration. That is, we could ask under what conditions would-be immigrants could reasonably be expected to accept the reality of frontiers. Reflection on that point would involve us in attempts to formulate an idea of relative over- and underuse of portions of the earth, where the relevant measure would not be per-capita occupation of two-dimensional territory, but per-capita occupation of three-dimensional space of differential usefulness for human purposes. Doing so would in due course also generate an argument in support of President Tong's proposal: After all, the more his islands disappear into the sea, the more the per-capita use his population makes of their region will increase (assuming a fixed population), and the stronger their claims to immigration elsewhere will be. The implications for immigration of the standpoint of collective ownership have been explored elsewhere, however; so here I merely record these points and move on to a different manner in which we can apply the standpoint of collective ownership to the Kiribati case. ${ }^{15}$

To get closer to the subject of human rights, note that the imposition of a state system (regardless of its moral virtues or prudential advantages) generates two problems for co-owners: it exposes them to the ex ante risks and ex post reality of finding themselves in conditions where their moral status as co-owners can be exercised at most in rudimentary ways if at all; and it allows them only limited exit options (if any) if they find themselves with an abusive government. In virtue of the concentrations of power that it includes, a state system readily has the power to violate the rights of co-owners, both by undermining their opportunities to satisfy their basic needs and by impeding their ability to relocate.

\footnotetext{
${ }^{15}$ For the subject of immigration in this context, see Blake and Risse (2007), Blake and Risse (forthcoming), and Risse (2008)).
} 
It is under these conditions that we must ask what to make of the immunity that individuals have from living under political and economic arrangements that interfere with those subject to them having opportunities to satisfy their basic needs. The relevant arrangement to which individuals are subject in this case is not merely the state in which they live, but the system of states per se. Each state, in virtue of its immediate access to individuals' body and assets, might deprive them of such opportunities, but so, crucially, might other states by refusing them entry if they cannot satisfy their basic needs where they live. At any rate, the claim just made is true of states that do have the ability to let people enter and allow them to satisfy their basic needs without making it impossible for some of their own citizens to do so. When individuals cannot satisfy their basic needs where they live, other states that have this ability but refuse entry would not merely fail to come to their aid; they would deny them the opportunity to satisfy these needs. Recall at this stage the right of necessary and other limitations on appropriation that we encountered in Grotius. It is this emphasis on the moral status of each co-owner that needs to be preserved regardless of circumstances, and in particular regardless of special political arrangements, that is strongly present in this non-theological version of the collective-ownership approach as well.

One might object that generally individuals who are threatened where they live do not have the opportunity to travel to another state to ask for entry, and therefore such states would not contribute to their predicament but merely fail to come to their aid. At any rate, they would only contribute to the predicament of those who make it to their borders and are turned away. But this under-describes the extent to which a state system based on self-determination and inviolability of territory contributes to such 
predicaments. Were our world no longer committed to such principles and were rich states more inclined to admit people who arrive at their borders because, say, their ability to make a living is threatened in their country of origin, organizations would spring up that specialize in making sure such individuals get to wealthier destinations. Such individuals would pay for these services by pledging future income, or charitable organizations would do this job. Or one might also object as follows. Suppose A and B own a boat together and somebody interferes with A's use of it. This, the objector would say, would not mean B has to stop that interference or else let A use the boat when B is entitled to using it. However, this is a wrong comparison. If A and B own the boat in common and this situation arises, and $A$ and $B$ are both in the boat, then $\mathrm{B}$ would have to give A refuge on her side, at least as long as the boat does not thereby turn over and thus condemn both people to drown.

Common ownership rights are natural, pre-institutional rights. Once institutions are founded, guarantees must be given to co-owners that institutional power will not be used to violate their status. Since such a violation is threatened by the system of states per se, such guarantees take on the form of moral demands against that system of states. Responsibilities that arise in the manner I have sketched must be allocated at the level of the state system as such, as collective responsibilities, rather than resting exclusively with individual states and then only with regard to their members.

5. But why would what I have said so far lead us to a conception of human rights? Cohen (2006) proposes that human rights have three features: they are universal and are owed by every political society to everybody; they are requirements of political morality whose 
force does not depend on their expression in enforceable law; and they are especially urgent requirements. Any more particular account of human rights, says Cohen, would have to meet these constraints, as well as two methodological assumptions: fidelity to the major human rights documents, so that a substantial range of these rights is accounted for; and open-endedness (we can argue in support of additional rights). Yet these criteria (which I agree do characterize the concept of human rights) do not entail commitments with regard to a range of questions about such rights. It is the function of a conception of human rights to provide a fuller set of answers to such questions. For instance, accepting these criteria does not imply that human rights must be understood as protecting essential features of personhood, as for instance Griffin (2008) argues. A different way of adding more detail to these criteria is to think of "human" rights as rights individuals hold qua members of the global and political order that ipso facto but contingently includes everybody. What I have argued above should be seen as work towards such a conception. That is, the standpoint of collective ownership gives rise to a set of rights that should be understood as membership rights in the global order. ${ }^{16}$

In what sense are human rights being held in virtue of membership in the global order? This order is the system of states that covers most of the land of the earth as well as the network of organizations that provides for "global governance." Our current global society arose from developments that began through the emergence of nation states and

\footnotetext{
${ }^{16}$ A conception of human rights, when fully developed, consists of four elements: First, an actual list of rights classified as human rights; second, an account of the basis on which individuals have them (an account of what features turn individuals into rights holders); third, an account of why that list has that particular composition, that is, a principle or a process that generates that list; and fourth, an account of who has to do what to realize these rights, that is, an account of corresponding obligations. Any fullfledged conception would offer answers to questions about human rights such as those listed above, and would also make clear both why such a conception is worth having and why the language of rights is appropriately used when we talk about "human rights." We will only need to deal with some of these issues here.
} 
the spread of European rule since the $15^{\text {th }}$ century, and the subsequent formation of new states through independence and decolonization. At the political level, the state system is governed by a set of rules, the most significant of which are codified by the UN Charter. At the economic level, the Bretton Woods institutions (IMF, World Bank, later the GATT/WTO) provide a cooperative network intended to prevent wars and foster worldwide economic improvement. These institutions, jointly with the more powerful states acting alone or in concert, shape the economic order. Importantly, for there to be enough structure to the global order to render that term ("global order") applicable, and an accompanying capacity for coordinated action, is a minimal condition for the existence of rights held within that order. And, indeed, there is enough structure of that sort. Being a member of that order merely means to live on the territory covered by it, which by now all human beings do, if for no other reason then because they all live on the territory of some state. So it does indeed make sense to speak of rights that are held in virtue of membership in the global order (assuming, of course, we can explain on what basis there would be rights of that sort). ${ }^{17}$

A virtue of this conception is that it makes plausible how human rights can be non-parochial, that is, how they can be of global reach and justify actions even against societies whose culture does not support those rights, and impose obligations even on people who have not caused the relevant problems. By construction, that is, this approach makes clear how certain moral concerns are of global reach (which is a common intuition

\footnotetext{
${ }^{17}$ My view does not presuppose that individuals "participate" in the global order. Even secluded tribes possess human rights. They are co-owners of the earth and are constrained by the imposition of the state system even if they do not actually feel the constraints. In the case of such tribes there presumably are unusually strong reasons to set aside enforcement of human rights. Yet if by any chance humans are discovered on the back side of the moon, the considerations explored in this study would not apply to them. That does not mean one can do with them as one pleases. But as they would not be members of the global order, these considerations would not bear on their moral status.
} 
about human rights, and one that stands in a difficult relationship to the idea that there are certain rights that human beings hold simply "in virtue of their humanity", see Raz (2007)). This approach also makes clear why the language of rights, rather than goals or values, is appropriate here. And at least as far as the standpoint of collective ownership as a basis is concerned, the foundations are extremely simple and obvious.

The main intuitive cost of the conception I am proposing, I suppose, is that it only grants limited space to the idea that "certain things simply must not be done to human beings, regardless of whether there is a global concern connected to it, and human rights capture that point." After all, this derivation of human rights is contingent because it appeals to a contingent, alas relatively abiding, global order. Yet I am not claming that this is the only sensible conception of human rights. One should not expect there to be a single philosophically most satisfactory conception of human rights. The sort of universality captured by the idea of human rights lends itself to different elaborations. One should therefore not judge this approach to human rights by asking whether it can make sense of everything one may have wanted to say about such rights, but by whether the idea of global membership rights is sensible and can accommodate a good range of central ideas about "human rights." The availability of different accounts of human rights may well help "to command reasoned support and to establish a secure intellectual standing” for human rights (Sen (2004), p 317).

6. Once we see how collective ownership of the earth gives rise to membership rights in the global order, it is a natural next step to turn around the direction inquiry and explore whether there are other bases on which such rights could be held. I have done this 
elsewhere (see Risse (forthcoming), Risse (2009a), but there is no need for us to pursue this here. Nor is there even a need to explore in detail what list of human rights we obtain in this way. What matters for our purposes is only this much: Using the stance of collective ownership for a derivation of membership rights leads to two fundamental guarantees that states and other powerful organizations must give, and whose realization is a global responsibility: first, they must make sure their power does not render individuals incapable of meeting their basic needs; second, they must provide opportunities for individuals to lead a life at least at subsistence level. A good deal of argumentative work still needs to be invested to get from these two fundamental guarantees to a sizeable list of human rights. However, if indeed such guarantees exist, the specific dangers imposed on individuals through the existence of the global order are neutralized vis-à-vis the status of which individuals are ensured in virtue of their common ownership rights. Recall, at this stage, that one such danger consists in the fact that the existence of states prevents individuals from going elsewhere if they cannot make a living, or continue to exist, where they live.

Now we can return to the Kiribati case. Recall an objection we have entertained above. That objection was that if two people own a boat and somebody interferes with one person's use of it, that fact by itself would not entail that the other person has to interfere or else let the first person use the boat when he would otherwise be entitled to using it. We saw that this objection was wrong-headed. If this situation arises when both are in the boat, the one person would have to let the other move over, at least as long as the boat is not hereby threatened to sink. This is in the relevant ways analogous the Kiribati case, and continues to be so if we do not specifically assume that a third person 
interferes with the one person's exercise of co-ownership rights, but instead merely assume that that one person finds herself unable to exercise her ownership rights at her location. It is arguable precisely how to characterize the conditions under which it is the case that people can no longer make a living where they live (and thus, to put it in terms of the boat analogy, can no longer stay on their side of the boat but have to move over), but what should be undisputed is that a scenario where that living environment itself is entirely or mostly submerged by water is a paradigmatic case in point.

Under those circumstances, there is no longer a way of respecting the troubled party's co-ownership rights by supporting them to make a living where they find themselves. Neither their own state nor other states can do anything to put them in a position to do so. The only way of respecting these rights, then, is for other countries to allow the affected people to immigrate, and this is something that is owed to them qua co-owners. Just as in Grotius' approach the right to necessity takes precedence over private property arrangements, so in this approach the right of these affected people would take precedence over a possible preference of other countries to keep them out. President Tong's proposal emerges vindicated from our investigation. There indeed is such a human right to relocation, and it would even include a demand against the host countries to put the new immigrants in a position to make a living given the economic parameters of their new home country. (It would not, however, include a demand against the host countries to cover expenses of training programs that would accomplish more than that.) Support from other countries for this plan, to that extent, would not be a matter of charity, but, again, a matter of putting into practice what the inhabitants of Kiribati are owed qua co-owners of the earth. 
7. Let me conclude by exploring one line of objection to my whole approach. One might say that the whole idea of humanity's collectively owning the earth is a misguided approach to environmental problems. The idea that humanity collectively owns the earth has played its part in the history of the unwarranted sort of human superiority: For instance, Gruen and Jamieson (1994) include excerpts from Locke (describing his version of the idea of collective ownership) in their collection of reflections on nature to make this point. But Egalitarian Ownership does not presuppose the arrogance associated with that particular interpretation of the biblical account that subjects the rest of creation to the human will, an attitude that shows, say, in Calvin's view that God took six days to create the world to demonstrate to human beings that everything had been prepared for them. In that way our approach differs from its $17^{\text {th }}$ century predecessors many of whose defenders took no issue with this implication. Nor does this view imply a commitment to the "rape" or "domination” of nature deplored in Horkheimer and Adorno's Dialectic of Enlightenment. ${ }^{18}$

Egalitarian Ownership is a view about the relationship among human beings and can readily be understood to be accommodating with regard to concerns, say, about the value of nature or the value of non-human animals: to the extent that we think nature is at our disposal, no human being has a privileged claim to resources. While the civil law often permits us actually to destroy objects owned in accordance with its prescriptions, Egalitarian Ownership does not entail the permissibility of wanton destruction, nor does

\footnotetext{
18 The biblical story can be read in different ways, see White (1967) and Passmore (1974), chapters 1 and 2. Passmore (1974) contains a wealth of information about the diversity of attitudes towards nature that have been held across cultural traditions. For the reference to Calvin, see Passmore, p 13.
} 
it commit us to ascribing merely instrumental value to nature. The ownership approach can readily integrate concerns about future people. Moreover, valuing nature intrinsically, as sublime or awesome, as providing a context where human life can obtain its meaning in the first place, or even as in some sense sacred is consistent with the view developed here. ${ }^{19}$

Yet not all attempts to reconsider our manner of valuing nature are consistent with Egalitarian Ownership. Aldo Leopold's credo -- “A thing is right when it tends to preserve the integrity, stability, and beauty of the biotic community. It is wrong when it tends otherwise” (Leopold (1949), p 224f) -- is not. Leopold suggests that at some point people will find practices of “owning land” as despicable as we find practices of "owning people." Such a "land ethic" moves outside of a scope of views one may call enlightened anthropocentrism, the position that all values ultimately must be values to human beings, values on a human scale, which, alas, does not mean their range is exhausted by instrumental values, or values of human flourishing, even broadly conceived. Enlightened anthropocentrism acknowledges that answers to environmental questions "must be based on human values, in the sense of values that human beings can make part of their lives and understand themselves as pursuing and respecting” (Williams (1995), p 234).

Deliberately outside of such a standpoint also moves, arguably, the "biospheric egalitarianism” of the Deep Ecology movement inspired by Arne Naess (Naess (1989)), according to which all living things (including plants and ecosystems) are alike in having

\footnotetext{
${ }^{19}$ For an overview of ways of thinking about the value of nature, see Krebs (1999). Wiggins (2000) emphasizes that nature is "sublime and awesome", and that our valuing it thus must have an impact on our attitudes towards it. Goodin (1992) defends the view that the value of nature lies in the fact that it gives us a context in which our lives can find a meaning. What is crucial about this context is that humans have not designed it.
} 
value in their own right. Approaches such as Naess's, while they may grant that it so happens that humans care more about each other than about other entities, will not give any morally privileged status to human projects: a rejection of alleged human chauvinism is part of their concern (see also Routley and Routley (1980)). They will not even tend to give such a status to the idea that human beings are "at home" in the world in the sense that they can sensibly think they can use the environment to satisfy their basic needs. Locke formulated that last point as follows: "The Earth, and all that is therein, is given to Men for the Support and Comfort of their Being” (Second Treatise of Government, section 26). At a minimum, this idea, stripped of theological content and connotations of human arrogance, must be acceptable within approaches to the question of how to value nature for Egalitarian Ownership to look plausible. But that idea is indeed compatible with a broad range of way of valuing nature.

So Egalitarian Ownership is not committed to any kind of human chauvinism. Its guiding idea is that any two human beings have symmetrical claims to independently existing resources, and that idea can be spelled out in a way that is consist with an integration of other moral concerns, especially concerns about the environment. Unlike Grotius, we can no longer safely rest our defense of the standpoint of collective ownership of the earth on religious foundations. Nevertheless, a secular version of this approach can help us greatly to think through a number of the normative issues that arise at the global level, especially such issues arising from climate change. The Kiribati case and other small-island cases form just one kind of example.

\section{Literature}


Becker, Lawrence. 1977. Property Rights: Philosophical Foundations. Boston: Routledge and Kegan Paul

Blake, Michael and Mathias Risse. Forthcoming. "Immigration and Common Ownership of the Earth," forthcoming in the Notre Dame Journal of Law, Ethics, and Public Policy Vol. 23 (special issue on immigration), available as a Kennedy School of Government working paper (RWP06-012)

Blake, Michael, and Mathias Risse. 2007. "Migration, Territoriality, and Culture.” In New Waves in Applied Ethics, Ashgate (ed. Jesper Ryberg, Thomas Petersen, Clark Wolf): pp 153-183 (joint with Michael Blake)

Buckle, Stephen. 1991. Natural Law and the Theory of Property. Grotius to Hume. Oxford: Clarendon

Caney, Simon. 2008. "Climate Change and the Duties of the Advantaged," forthcoming in Critical Review of International Social and Political Philosophy

Caney, Simon. 2006a. "Global Justice, Rights and Climate Change,” Canadian Journal of Law and Jurisprudence, Vol. XIX no.2, pp.255-278

Caney, Simon. 2006b. “Environmental Degradation, Reparations and the Moral Significance of History,” Journal of Social Philosophy, vol.73 no.3, pp.464-482

Cohen, Joshua. 2006. "Is there a Human Right to Democracy?” In Christine Sypnowich (ed.), The Egalitarian Conscience: Essays in Honor of G. A. Cohen. Oxford: Oxford University Press, pp 226-249

Edmundson, William. 2004. An Introduction to Rights. Cambridge: Cambridge University Press 
Gardiner, Stephen. 2004. "Ethics and Global Climate Change.” Ethics 114: pp $555-600$

Goodin, Robert. 1992. Green Political Theory. Cambridge: Polity Press

Gosseries, Axel. 2005. “Historical Emissions and Free Riding,” In Lukas Meyer (ed.), Justice in Time: Responding to Historical Injustice. Bade-Bade: Nomos, pp 355380

Griffin, James. 2008. On Human Rights. Oxford: Oxford University Press

Grotius, Hugo. 2005. The Rights of War and Peace. Edited with an Introduction by Richard Tuck. Liberty Fund: Indianapolis

Grubb, Michael, and James Sebenius, Antonio Magalhaes, and Susan Subak. 1992. "Sharing the Burden.” In: Irving Mintzer (ed.), Confronting Climate Change: Risks, Implications, and Responses. Cambridge: Cambridge University Press, pp 305-322

Gruen, Lori, and Dale Jamieson. 1994. Reflecting on Nature. Readings in Environmental Philosophy. New York: Oxford University Press

Hart, H. L. A. 1982. Essay on Bentham. Oxford: Oxford University Press

Honore, A. M. 1961. “Ownership.” In Making Law Bind: Essays Legal and Philosophical. Oxford: Clarendon

Hospers, John. 1971. Libertarianism. Nash Publishing: Los Angles Krebs, Angelika. 1999. Ethics of Nature: A Map. Berlin: de Gruyter Leopold, Aldo. 1949. A Sand Country Almanac. Oxford: Oxford University Press

Locke, John. 1960. Two Treatises of Government. Edited with an introduction by Peter Laslett. Cambridge: Cambridge University Press 
Malanczuk, Peter. 1997. Akehurst's Modern Introduction to International Law. Seventh Edition. London: Routledge

Naess, Arne. 1989. Ecology, Community, Lifestyle. Cambridge: Cambridge University Press

Passmore, John. 1974. Man's Responsibility for Nature. London: Duckworth

Raz, Joseph. 2007. “Human Rights Without Foundations.” University of Oxford Faculty of Law Legal Studies Research Paper Series, Working Paper 14/2007

Reeve, Andrew. 1986. Property. Atlantic Highlands: Humanities Press

Risse, Mathias. Forthcoming. ”Human Rights as Membership Rights in the Global Order.” Available as Kennedy School of Government working paper (RWP08006)

Risse, Mathias. 2009a. “A Right to Work? A Right to Leisure? Labor Rights as Human Rights," to appear in Journal of Law and Ethics of Human Rights; available as Kennedy School of Government working paper (RWP07-058)

Risse, Mathias. 2009b. “Common Ownership of the Earth as a Non-Parochial Standpoint: A Contingent Derivation of Human Rights,” to appear in the European Journal of Philosophy; available as a Kennedy School of Government working paper (RWP07-033)

Risse, Mathias. 2008. "On the Morality of Immigration," Ethics and International Affairs 22 (1): pp 25-33

Risse, Mathias. 2005a. "How Does the Global Order Harm the Poor?," Philosophy and Public Affairs 33 (4): pp 349-376 
Rothbard, Murray. 1996. For a New Liberty. The Libertarian Manifesto. San Francisco: Fox and Wilkes

Routley, Richard and Val Routley. 1980. "Human Chauvinism and Environmental Ethics.” In D. Mannison, M. A. McRobbie, and R. Routley (eds.), Environmental Philosophy. Canberra: Australian National University, pp 96-189

Ryan, Alan. 1987. Property. Milton Keynes: Open University Press

Sen, Amartya. 2004. "Elements of a Theory of Human Rights." Philosophy and Public Affairs 32: pp 315-357

Shue, Henry. 1996.”Environmental Change and the Varieties of Justice.” In Fen Osler Hamilton and Judith Reppy, Earthly Goods. Environmental Change and Social Justice. Ithaca: Cornell University Press, pp 9-29

Shue, Henry. 1999. "Global Environment and International Inequality." International Affairs 75 (3), pp 531-545

Singer, Peter. 2002. “One Atmosphere.” Chapter 2 of One World: The Ethics of Globalization. New Haven: Yale University Press

Tuck, Richard. 1999. The Rights of War and Peace. Oxford: Oxford University Press

Vallentyne, Peter, and Hillel Steiner (eds.). 2000a. The Origins of LeftLibertarianism: An Anthology of Historical Writings. New York: Palgrave

Vallentyne, Peter, and Hillel Steiner (eds.) 2000b. Left-Libertarianism and Its Critics: The Contemporary Debate. New York: Palgrave

White, Lynn. 1967. "The Historical Roots of our Ecological Crisis.” Science 55: pp 1203-1207 
Wiggins, David. 2000. "Nature, Respect for Nature, and the Human Scale of Values.” Proceedings of the Aristotelian Society 100 (1): pp 1-32

Williams, Bernard. 1995. "Must a Concern for the Environment be Centered on Human Beings?” In Making Sense of Humanity and other Philosophical Essays (pp 233241). Cambridge: Cambridge University Press 